\title{
GESTALT THERAPY FOR SOLDIERS AND SAILORS' COUPLES AND FAMILIES BY APPLYING DANCE AND MOVEMENT THERAPEUTIC EXPERIMENTS
}

\author{
Dr. Laima Sapežinskienè \\ Lithuanian University of Health Sciences \\ Alvydas Soraka \\ Klaipéda University \\ Daina Milikauskienė \\ Lithuanian University of Health Sciences
}

\begin{abstract}
Annotation. The article aims at revealing the possibilities of application of dance and movement therapeutic experiments in consultations of soldiers and sailors couples and families. The article discusses the essential principles of Gestalt therapy in applying dance and movement therapy for couples and families, who start creating their couple life or are willing to change, to improve their current presence in the couple or in the family. In order to get answers to the issues of the research, i.e., "What happens, when we are dancing in couple? Moreover, what happens in the marriage, the couple life?", we have analyzed the metaphor of "the dance of the couple, family life" through the experiences of the contact cycle. We have provided the results of the theoretical - practical research of changes in couples and families as several pre-defined categories: 1) dual reversibility: exchange of the same behavior; 2) interaction synchronization; 3) other possible models of the couple and family life dance.
\end{abstract}

Key words: Gestalt therapy, contact cycle experience; dance and movement experiments; couple / family life dance; Argentine tango.

Introduction. The most common reasons that encourage couples / families to seek the support of the couple / family therapy are lack of love, intimacy and mutual understanding, communication difficulties, conflicts, crises, thoughts of divorce or separation, the desire not to feel distant from each other and to recover or develop the harmony of mutual relations. More than 65 percent of Lithuanians state that quality relationship with the spouse or partner is the most important thing in life for them, the importance of which is surpassed only by the financial security (Stankuniene et al. 2003; 2003a). Good mutual relations are equally important 
for people of all ages, both women and men (Maslauskaite, 2005: 26). Couples / families "come to therapy because they are caught in a cycle of disappointed hopes, of hurt and anger, and they know that they are destroying their love for one another in spite of their good intentions" (Wheeler \& Backman, 1994: 83).

The representative of Gestalt therapy Virginia Satir (1986; 1988), who can be called the mother of American family therapy, claimed that the purpose of the marriage therapy is not "to maintain the relationship or to make the couple separate, but to help the partners to take care of themselves." The effective couple therapy focuses exactly on the partner differentiation rather than pursuit to "align them and adjust to each other". Gestalt therapy focuses on being with oneself and the others, analyzing what is happening, i.e., what experience is gained during the social contact. Using one of the two definitions of the self, that the self is a system of contacts in the organism/environment field, there is the scope to move beyond the separate ego sense of self to many selves, which arise and come into being and then fade back into the ground. Hence, when two or more people become systematized in their contact with each other, they are a self (Perls et al., 1951). We have used this approach, being one of the main systematic approaches to a couple / family, for couples and families, who either start creating their couple life or are willing to change, to improve their current presence in the couple or in the family.

Gestalt therapy focuses on the immediacy of experience as emotions and feelings are brought into awareness to challenge pre-existing patterns of thinking and action (Yontef, 1993, cited from Olivieri \& Fiebert, 2013). Gestalt is a German word that does not easily translate into English. Its central meanings include form, shape, manner, aspect, kind, and character. These meanings were adapted in Gestalt psychological and psychotherapeutic theory to signify a pattern, a whole, a discernible configuration or constellation. However, for a description of the word, the essence, if you will, "three phenomena must be considered: a thing, its context or environment, and the relationship between them."

For example, in this article in most cases we have viewed a couple / family or their relationship and interactions as a certain gestalt. However sometimes one partner of the couple can feel or discover that he / she only imagines that the family is "complete", while the other partner is not nearby, and in this case the gestalt will be his / her experienced self. Founded by Frederick and Laura Perls, this phenomenological-existential approach brings together a type of "stepping outside of one's self" to discover a clear and fresh perspective for the individual in relating to his or her environment (Yontef, 1993, cited from Olivieri \& Fiebert, 2013). Gestalt therapy focuses on being with oneself and the others, analyzing what is happening during the social contact. Roubal (2009) posited that the core of Gestalt therapy is not only working to integrate the polarities of an individual's personality, but equally essential is working within the therapeutic polarities of dialog and taskexperimentation (Olivieri \& Fiebert, 2013).

The couples and families of soldiers (in the authors' opinion, the same applies 
to the couples and families of sailors or other employees of statutory organizations) are characterized by a feeling of exclusion and loneliness, when both the remaining spouse and the returning one suddenly discovers this feeling. There are only few efforts to teach the soldiers' families how to prepare for return of a soldier (Robinson, 2010). Based on their work particularity, soldiers and sailors make a social group that is isolated from their family, relatives and friends, as well as from the external media sources. Upon returning home, they have to adapt to a normal life, to make radical changes of habits and rhythm of life, which again causes a number of social and psychological problems. The analysis of sailors' self-development needs provides a deeper understanding of peculiarities of their life and activities, helps to understand their problems, to establish the nature of their relationships with others and themselves, and to realize that the family is one of the most important values in their lives (Zukauskiene, Virsilas, 2005). For majority of persons the military service is beneficial, but some individuals experience both health disorders and behavioral and social problems due to growing military service experience (Hatch et al., 2013; Iversen et al., 2009; MacManus et al., 2012a, 2013; Rowe et al., 2013).

The contemporary military educational paradigm implies the need to develop an officer, not only as a commander and a leader, but also as a scientist, a teacher, a technician and a manager. Special requirements are set for developing the officer's guiding values and moral provisions (Challenges of Globalization in Educational Process: the Society and the Army, 2013:4). Military service is reasonably attributed to the most complex activities. Soldiers often have to work in very difficult conditions that are dangerous to life and health, to bear physical loads, to experience a variety of psychological and spiritual shocks and challenges (Cikalova et al., 2013:83). They must be willing to quietly accept and endure the horrors of battle, not to be disturbed in difficult and dangerous circumstances, to have knowledge about psychological phenomena taking place in the battlefield and other emergencies (Puzinavicius, 2001; 2007, cited from Cikalova et al., 2013:83). The "soldier type" is named as "passive aggressive", which reveals the fact that the soldier often has to reconcile the opposing notions of the "war" and "civilization", "sociability" and "individualism" inside himself. (Cikalova et al., 2013: 83).

Considering the above, we can pose a research question of how to help the soldiers and sailors shape the alternatives of transition from the statutory to the civilian life, in order to reduce psychosocial problems and conflicts in the inner and interpersonal levels? Goal: to reveal the possibilities of application of dance and movement therapeutic experiments in consultations of soldiers and sailors couples and families during Gestalt therapy sessions.

Issues of the research: "What happens, when we are dancing in couple? Moreover "what happens in the marriage, the couple life?" Can Gestalt therapy experiments (dance and movement experiments) help change the frozen patterns of relations and interaction of a couple / family? In other words, are adults able to change and to be flexible in creating social contacts? 
Objectives: 1) to define the key principles of Gestalt therapy in applying dance and movement therapy for couples and families, who start creating their couple life or are willing to change, improve their current presence in the couple or in the family; 2) to establish the qualitative results of the single case analysis, by applying the metaphor of "the couple, family life dance". The phenomenological qualitative research methods have been applied, namely a case study. The data have been collected using the narrative (the authors' note - conversation, covering the autobiographical specificity and reflective sharing of the experience of what happened during the experiments of dance and movement therapeutic exercises. The narrative data (Warwar et al., 2011) have been analyzed and handled by means of the content analysis. The family attending the Gestalt therapy-counselling (total 10 sessions) has participated in the research. The duration of each session has amounted to 1.5 h. 5 sessions have been dedicated to verbal therapy, and the other 5 sessions have included the dance and movement therapeutic experiments (Argentine tango).

In response to the objectives assigned to the research, we have expounded the theoretical and research material in the two sections. The first section "Methodological Concept of Neuroplasticity" and the second section "Essential Principles of Gestalt Therapy" present the research methodology. The third section describes the "Dance and Movement Therapeutic Experiments for Couples and Families". The fourth section is dedicated to the results of the theoretical - practical research of changes in couples and families.

\section{Methodological Concept of Neuroplasticity}

Genetic and early experience shape the human brain and behavior, but, according to neuroscientists "we are not doomed by our genes and the past" (Frisbane, 2013). The brain is plastic and it can change its function to adapt to changing demands of various kinds (Moller, 2006). Neuroplasticity research proves the patterns of empathy development and self-regulation, which suggest that adults are subject to change as well. Facilitating change in couple therapy by understanding how the brain works to maintain - and break - old habits (Fishbane, 2013:11).

More and more evidence-based researches are carried out, proving that dance and dance movements develop neuroplasticity. Dancing is an activity that emerged from a need for social interaction and non-verbal communication, and it is a universal human expression consistent across generations, cultures, and social classes throughout the world (Kattenstroth et al., 2013). Compared with other activities, such as exercise or playing a musical instrument, dance comprises rhythmic motor coordination, balance and memory, emotions, affection, social interaction, acoustic stimulation, and musical experience apart from its requirements for physical activity. This unique combination of properties makes dance a potentially powerful interventional approach (Kattenstroth et al., 2013). 
For these reasons, dance has been established as a therapeutic tool for the treatment patients with serious mental illness (Hackney \& Earhart, 2010). Dancing is increasingly used as an intervention because it combines many diverse features making it a promising neuroplasticity-inducing tool (Kattenstroth et al., 2013). By learning to dance and dancing in couple the brain activity is affected. This is socalled vicarious activation - activation of a brain region that is normally involved in processing the observer's own actions and sensations, but that is now activated by seeing similar proprioceptive actions or sensations in another person (Habib, 2005). The notion of "proprioception" means that: "In muscular receptivity we see the body itself acting as a stimulus to its own receptors - the proprioceptors." In a strict interpretation of that definition, many types of proprioceptors, not just those concerned with muscular sensibility (Proske \& Gandevia, 2012), supply our bodies. Several researches have proven that during dancing the aesthetic experience of movement and dance is sensed through the proprioceptors, felt inside the body, muscles, tendons, joints, i.e., kinesthetic and vestibular system (Vukadinović and Marković, 2011:24-25).

Dance, movement and emotions experienced while dancing make a positive effect on thinking and brain activity (Hagendoorn, 2005; Hangendoorn, 2011; Sevdalis, Keller, 2011; Meekums, 2005; Karkou, 2009; Meekums et al., 2015). During dance the image / scheme of the partners' bodies changes. It has been found that the body image / scheme development is going on from infancy, when soon after birth humans show a strong innate tendency to mimic sounds and motor acts, copying orofacial movements performed by adults before them (Proske \& Gandevia, 2012). Such behavior supports the existence of mirror neurons, with imitation providing the basis for an understanding of the relationship between oneself and others. The functioning of mirror neurons takes an important part in this process (Gallese et al., 2007; Samaritter, 2009). The function of mirror neurons offers a more comprehensive picture of some physiological reasons of why mirroring can be an effective way of engaging clients in the therapeutic process (Karkou, 2009).

Similarly, through dance and movement therapeutic experiments the socalled "mirroring" technique is used. Mirroring, in the way, is often practiced in psychotherapy. This therapeutic technique has originated from Marian Chace (Chaiklin and Schmais, 1986) in the 30s and 40s (Karkou, 2009). Since then it has developed into a central technique with a wide range of different client groups, which reflects the important role of empathy within this practice and its strong influences from humanistic psychotherapy (Karkou and Sanderson, 2006). Currently, mirroring receives renewed attention from dance movement psychotherapists, other professionals and researchers due to discoveries in neuroscience regarding mirror neurons in particular (Rizzolatti et al., 1996; Brown et al., 2006; Moller, 2006; Winters, 2008). 


\section{Essential Principles of Gestalt Therapy}

Viewing couples / families from the systematic point of view, as all of us, a couple somehow expects to receive satisfaction through couple therapy (Mebius, 2009). Kepner (1987) shows that a client's posture, movements, and bodily experiences are indeed relevant to therapy, and he offers an insightful framework for incorporating these aspects into a therapeutic framework. Taking into account the importance of the body and body processes in psychotherapy, we apply the methodological Gestalt therapy approach, with its emphasis on the personality change both in individual and couple level through changing experience of the social experiment (hereafter - contact).

\subsection{Methodological Gestalt Therapy Approach}

The essential principles of Gestalt therapy are methodologically interpreted and based on the main beliefs of the systems theory and phenomenological theory. The three basic interrelated principles of Gestalt therapy (Clarkson, 2014: 33) reveal that the phenomenological theory must be applied in order to detect the effectiveness of Gestalt therapy for a couple / family. The first principle: Gestalt therapy is phenomenological, as its main goal is awareness; this method is particularly dedicated to exploring the awareness of a couple / family. The second principle: Gestalt therapy is based on dialogical existentialism, i.e., how a couple / family experiences the processes of movement to contact and retreat from contact of "I - You". The third principle: the conceptual framework of Gestalt therapy, in other words the "worldview" is based on holism and field theory, by revealing what worldview is seen and perceived by each partner individually and by the couple / family in general.

Thus, the psychotherapeutic dialogue, taking place between the psychotherapist and the couple / family reveals the phenomenologically observed reality, covering each of them and their environmental context. The system would include the totality of "self and other", as well as the separate subsystems of "I" and "You" and their respective environments. "To empathize with another means to reconstruct the experiences of another person in oneself. Empathy is necessary to understand and sympathize another person, because their experiences are not given directly to us. Empathy implies that I have to restore another person's experience in my inwardness, i.e., in my experience“ (Jonkus, 2009: 201). Gestalt therapy theory attaches great importance to the perception of dialogical relationship, i.e., awareness and attentiveness of body experience, and applies qualitative research experimentation, which is based on Levin's field theory, clinical practice phenomenology (Yontef, 2002; Lahood, 2013: 123).

Analysis of a couple / family and their relationships and interactions as a system is a complex process, requiring skills and competencies. One of the ways helping to understand the couples and families is use of metaphors that emerge 
phenomenologically and their application to pursue changes in a couple / family. Ropes as a therapeutic tool can be seen as a metaphor for family relationships, to demonstrate how one part of the family system affects the rest of the family (Satir \& Baldwin, 1983: 160). In observing and analyzing her clients over the years Satir has determined that in pursue of changes in their lives, they are involved in the change process by learning to accept more willingly the forms of communication of their own and the others. This change process involves six stages: (1) "status quo"; (2) foreign element; (3) chaos; (4) integration; (5) practice; (6) new "status quo". (Satir et al., 1991; Satir, 1988; Grakauskaite-Karkockiene, 2011).

Following the essence of Gestalt therapy, we choose methodologically the metaphor of "couple / family life dance" for the analysis of the couple / family (Zinker, 1994), which is revealed and analyzed using the qualitative method through Gestalt contact cycle (which also has a metaphorical sense) experiences (Yontef \& Bar, 2008). Other metaphoric notions of the couple / family relationship can emerge directly during the verbal or creative educational experiments or after them.

The supplementing metaphor, revealing the experiences of a couple / family and closely related to the Gestalt cycle of experience is one of the Satir's metaphor applied for family psychotherapy, namely the metaphor of an "iceberg" (Satir et al., 1991). As an iceberg, the family is only merely above the water and thus open to the environment, the rest being kept under the water. Every member of the couple / family has two sides as well: 1) the external one, available to the environment, and 2) the internal one, invisible to the environment. We will further on analyze in more detail the cycle of the couple / family contact experiences used in Gestalt therapy.

\subsection{Gestalt Cycles of Contact Experience}

Gestalt therapy theory explains the experience of "here and now" with oneself and the others by the social cycle of contact experience. It serves to diagnose the person's needs and find out how they are identified and satisfied. Gestalt theory uses the word contact as an abstract, formal concept that refers to the exchange between an individual person and the surrounding environment (Miller, 1994; Wagner-Moore, 2004:181-182). A way of understanding our needs and how we can satisfy them completely is reflected in the changing Gestalt cycle of contact experience. The Gestalt cycle of experience in body process is depicted by Kepner (1987) as a wave of phases; sensation, figure formation, mobilization, action, contact, withdrawal (Fig. 1).

Each partner can perceive the other partner and / or common atmosphere of the couple / family as the environment, being a source of creativity or pretext for unsatisfied needs and / or general dissatisfaction in contact with another. Disruption or incomplete termination of the contact cycle is also called a creative adaptation of the couple / family to the reality that is created by the couple / family and the environment. For example, in case of depressive symptomatology, it can be persons' 
creative adaptation, because a social biological perspective presents the depressive syndrome as an adaptive mechanism within a society (Roubal, 2004; 2007: 41). Thus, persons' true creativity influencing adaptive adjustment to the environment, while keeping the possibility to satisfy own needs, is lost; the contact boundaries are distorted and do not comply with the realistic moment; and one sinks into the trajectory of suffering or cycle in the couple / family.

"Suffering is always phenomenologically visible at the contact boundary where lived-bodies emerge: the inter-corporeity is the dimension where suffering reveals itself and it can be met and cured" (Mearleau-Ponty, 2002; Francesetti et al., 2013: 73). Riemann and Schütze (1991), while talking about the "trajectories of suffering", emphasize that social processes structured by a certain chain of events cause various disorders, determine their crises and become the ground of complicated situations. Based on a new definition of the life situation the person starts a systematic action scheme of controlling or escaping from the trajectory dynamics (Riemann \& Schütze, 1991: 351). The suffering is experienced by individual human beings; it has a deep impact on their lives and personal identities. The severe suffering shapes their individual biographies; it changes the individual's relationship to her or his personal identify, social relationships, and social worlds (Riemann \& Schütze, 1991: 338)

It is important to note that Gestalt therapy makes it possible to release oneself from the supposed imprisonment, fixation, extending trajectories of suffering and move on to the next potential trajectories of activity, to restore the true creativity through creative restructuring of interpersonal relationship, not "there and then", but rather "here and now", by using experiments.

The adaptation of Bourdieu's concept of "social trajectory" enabled the data to be analyzed by comparing them with a similar trajectory for the dance process but these were not fixed points and the journey was not a steady progression (Oliver, 2009: 212). In keeping with Bourdieu's (2005) use of the term, the dancers skipped back and forwards along the trajectories. The social journey started with individual reasons for embarking on this particular journey, moving through emotional reactions and the creation of their art to the social end of the spectrum where they gain experience and confidence through interaction, and start to take control of their artistic product and social standing.

\subsection{Experience of Experiment through the Contact Cycle}

The important point is that in pursuing the changes in the couple / family relationship it is necessary to realize that changes arise through experimental experience. Gestalt therapy explores through experiments the extent to which the couple / family have contacts, relationship and interactions with each other (Zinker, 1983; 1994; Zinker, 1977; Zinker \& Cardoso-Zinker, 2001; Wheeler \& Beckman 1994). What partners of the couple / family say to one another is of secondary 
importance? It might be that one or both partners lose interest in each other, and sometimes they interrupt the other and none of them is allowed to complete, to express what they have meant to say.

Gestalt therapist observes and analyzes the way of contact of the couple / family, and draws the attention of the couple / family to their behavior, when their contact is not functioning or, in other words, "unhealthy". Some couples / families, who attend the counselling for changes in their life, the deeper awareness of what is going on in their life is enough, while the others need experiments suggested by the Gestalt therapist, so that each member of the couple / family could otherwise perceive a lack of contact with each other or the ongoing changes.

The examples of such experiments might be search for feeling; variation in physical distance and sentimental reaction to that; the experiment of "eye contact" and the later discussion the meaning of "eye contact" in the past and present situation; search for active and inactive contact, or otherwise - identification of the "creative emptiness" (Mebius, 2009) or chaos (acc.to Satir). If all couples seek for the satisfying relationship, it is important to analyze the energy and speed of emergence of the social contact in the couple that satisfies both partners (Fig. 1):

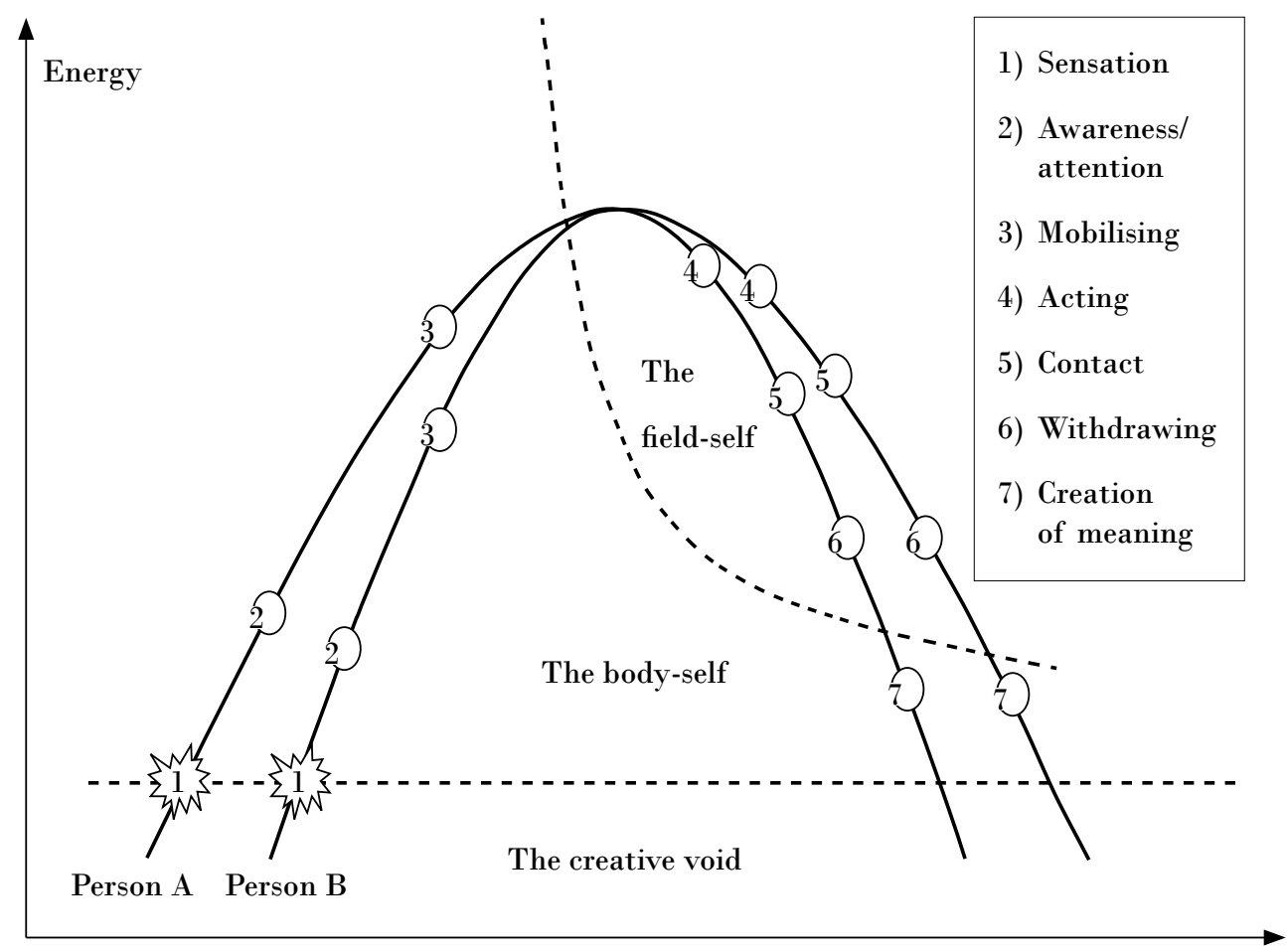

Fig. 1 Gestalt contact cycle for couple (Nevis, 1987; cited Mebius, 2009). 
Harmonization and adaptation of two individuals in the social environment (field) of the couple is demonstrated by shows the Gestalt contact cycle of their individual experiences. In order to adapt the cycle of experience to a field perspective, it is necessary to see how two or more people's cycles of experience relate to one another (Mebius, 2009). The figure shows what it could look like in an ideal situation between two people in e.g. a love relationship. The two people have different rhythms concerning a need, but their cycles have approximately the same peak of quantity of energy. Thus, person one starts earlier and has a longer cycle than person two, but they have the same commitment concerning the need (Mebius, 2009).

When the couple, i.e., both partners and the notion of "we" perceived by them, enter the "creative emptiness" or chaos, there occurs a possibility to change, grow, heal for both partners individually and the couple as a whole (Mebius, 2009). Wheeler (1991) opposes Perls, Hefferline and Goodman's thoughts that the person who does not have a powerful contact makes an interruption in the contact with her environment. He thinks that a person is always in contact with her surroundings, otherwise she / he does not survive.

The couple therapy is similar to dance and vice versa. Integrating experiences of love and sexuality in psychotherapy cannot be reduced to a technical fact; rather, it requires the co-creation of a contact-boundary where the values, personalities, and ways of dealing with life of both couple and therapist play a fundamental part (Spagnuolo Lobb, 2003; 2009).

\section{Dance and Movement Educational and Therapeutic Experiments}

In terms of Gestalt therapy experiment is an activity that encourages greater perception and awareness of the client (in this case, the couple / family) awareness (Greenberg \& Kahn, 2015:23). According to Brownell et al. (2008:16) this reflective awareness means the capacity for continual observing, interpreting what is going on, deriving and creating unique meanings, choosing intentions, and in this sense, being the source of what is actual for a person. Experience is what we consciously realize through our experience and accept it.

\subsection{Dance and Movement Experiments}

The education therapeutic activities of dance and movement is related to the historic roots of Gestalt therapy. Growing out of Laura Perls' background in dance, Fritz Perls' background in theater, and his studies with Wilhelm Reich, Otto Rank, and Jacob Moreno, Gestalt therapy added a powerful new dimension to the "conversational" varieties of psychotherapeutic work that preceded it (Kim, \& Daniels, 2008). An "experiment" may be suggested by a Gestalt therapist to guide a client toward discovering what is important for her/his growth by participating in a direct experience, when acting is preferred to talking about that. 
The dance or movements themselves are actually practical experimental experience of the partners happening "here and now". Popular contemporary representative of Gestalt therapy for couples / families Resnick (2004: 40-64) states that creative experiments are very important both during couple / family counselling, and as homework experiments. The couple / family counselling may include special breathing or meditating touch experiments as separate elements or integrating them into the dance and movement experiments.

Considering the systems theory, conflicting couples are involved into recurring conflicts that are characterized by primitive relations (Levite \& Cohen, 2012b). In fact, such dynamics create a cycle of terror, retaliation, and failed reparation attempts that in turn leads to further terror, splitting and projection, with the resulting outcome often a high-conflict divorce (Levite \& Cohen, 2012a). In order to help couples / families to solve the recurring conflicts, it is appropriate to allow them to learn to behave otherwise. In other words, a couple that acts as a system, always has the potential to develop the system elements, by completing the experiment related to the problem (Satir, 1997; 1978; 1986; Satir \& Baldwin, 1983; Satir et al., 1991; Loeschen, 1998; Rescnik, 2004). The awareness experiments are performed in various ways: they can be verbal and non-verbal, intended to test unusual behavior patterns.

The main experiments include the imagination experiment and the so-called "empty chair" experiment (Greenberg \& Kahn, 2015: 24), when each partner can "experiment" acting the role of another. Similar to the "empty chair" experiment, dance and movement therapeutic experiments are applied during the couple / family counselling. The researches confirm that dance and movement therapeutic experiments are effective (Meekums et al., 2005; Meekums et al., 2015). The authors of the article believe that by introducing dance in couples / family counselling the partners can be offered to perform the same dance scheme, upon exchange of the roles in couple; or to perform the partner's steps alone, without the other, but imagining that he/she is dancing in couple.

From the phenomenological point of view pairing as a passive association refers to the manner in which the other appears as other (Gutauskas, 2010: 89). According to Gutauskas, if the other indicates oneself as the other "self", how can his/her "self" be perceived? Such experiments are called the "dialogue" experiments. They are more efficient, because they simplify solution of internal conflicts and unfinished issues (Perls, 1969; Greenberg \& Kahn, 2015: 24).

The experiments with couples / families, where the partner roles are changed, can be theoretically explained by applying Merleau-Ponty's insight: "The dialogue experience between me and the other constitutes a common area, my thoughts and the thoughts of the other weave the same fabric, the debate condition evokes my remarks and remarks of the interlocutor, intervening into the overall operation, which is neither my creation nor the creation of any other person. (...) We are perfect reciprocal cooperators to each other. Our perspectives seamlessly transfer into one another; we 
co-exist in the same world. The thoughts of the other really belong to him / her; I do not formulate them, even if I catch them at the very dawn of them or anticipate them...." (Mearleau-Ponty, 2002; Gutauskas, 2010: 108). All this can be transferred by conducting dance and movement experiments in the perspective of Argentine tango.

\subsection{Experiments by Applying Argentine Tango}

In the couples / families counselling and conducting dance and movement therapeutic experiments the fundamental principle is that, for example, the use of Argentine tango (hereinafter - AT) as a therapeutic and educational tool, partners are assisted to experiment, identify, investigate and express their emotions through body movements, both individually and together as a couple. Especially in case of depression, the therapeutic technique that uses AT dance integrated with special exercises is an effective therapy (Meekums et al., 2015). Suitably instructed diverse specialists in psychotherapy, education, and other areas of health care can apply this method (Woodley \& Sotelano, 2011).

Recently, psychotherapists in Europe have begun to explore the use of AT as an aid to personal growth and even in the treatment of emotional trauma, depression and social anxiety (Polo, 2010). Its eight AT basic steps represent the eight basic steps of love. In a genuine tango, man and woman are equal, but not the same (Woodley, Sotelano, 2011). Both are mutually responsible for the relationship - and for the success of the AT. Both man and woman simply need to finalize the use of "learned steps", since by automatically repeating the routine movements the partners are not able to create a general motion and find the best possible position, while being together (Sartori \& Steidl, 2000: 60). However, each person has his or her individual role. Being part of a couple is like a dance: the closeness and distance, the longing for independence and connection. In the vortex of ambivalent emotions, we are spun around within our relationship (Woodley, Sotelano, 2011). AT is a complex art form that involves a sustained, emotional dialogue with another, communicated through the embrace and embodied in a choreographed walk, which can be accented with leg entwinements, kicks, turns and rapid footwork (Woodley \& Sotelano, 2011).

AT lyricism intertwines with tragedy and irony, which allows relatively reflecting the depth of social relationships in the social trajectories of a couple or family. While dancing AT, there is an opportunity to improvise in couple, to reconnect and communicate emotionally and physically, to move together through the intimate dialogue processes and new creative trajectories.

\section{Results of the Theoretical - Practical Research of Changes in couples and families}

The family (husband and wife) attending the Gestalt therapy-counselling (total 10 sessions) has participated in the research. The duration of each session has 
amounted to 1.5 h. 5 sessions have been dedicated to verbal therapy, and the other 5 sessions have included the dance and movement therapeutic experiments (AT exercises). Simple AT exercises have been demonstrated individually and in couple. While dancing, the couple has been instructed to pay attention to their feelings (what do they feel as man and woman in couple, how they feel each other). After the sessions, the reflections have been recorded. The couple has been counselled due to microclimate of the family (the husband is often away to business trips for two weeks or longer; the wife must act alone and solve all the household issues); and the wife's depressed mood, dissatisfaction with life, and negative attitude towards her body. The participants of the research have shared their reflections about their autobiographical specificities and experiences gained through the dance and movement educational and therapeutic experiments. The aspects of marriage and couple life have been analyzed in the sense of Gestalt therapy, by applying the basic metaphor of the "couple, family life dance", which has covered other supplementing metaphoric expressions as well: "creative emptiness", "chaos", "iceberg", "cycle of trajectory of suffering - competition", "cycle of trajectory of plasticity - adjustment and targeted dance", etc.

The results of the research have been divided into several pre-defined categories, upon application of the qualitative research method (Thompson \& Harper, 2012): 1) dual reversibility: exchange of the same behavior; 2) interaction synchronization; 3 ) other possible models of the couple and family life dance.

The couple under research has gained new behavioral skills. They have become aware of their power to change and that the model of suffering, sacrificing and creation of anger trajectories is not the only one in life; but rather they can become the authors of their new life models (Scheinkman \& Fishbane, 2004). The partners have obtained the skill to utilize the dual reversibility: when the partners exchange the same behavior in the couple life (one makes tea to another or one makes the other's feet warm, when the partner is tired or cold...); interaction synchronization (alignment in couple, as if dancing tango, despite different steps and actions), or interpersonal interest in each other, when the acting speed is decreased and one allows oneself to slowly view own life moments from the distance, as if freezing them and learning how to manage them (Goldner et al, 1990). After the experiments, the woman has found out and understood that her body postures and senses are related to unfinished gestalts from her childhood, when her father had expected a boy rather than a girl. The client has continuously tried to meet her father's expectations and to walk, act as a man, although deep in her heart she has aspired to be a real woman. This has also increased her dissatisfaction, discomfort during sexual intercourse or total distancing, ignoring. She has understood why she had never experienced pleasure in dancing with a man. She has become aware that she cannot occupy the "commanding" level all the time in the dialogue, because competition is not the only way of communication. The husband's "revelation" has not been less. Although he had considered himself a good dancer, he has been surprised by a very 
new experience of dancing, which has allowed him to see his wife in other light and to discover new, interesting relationship that has turned to be satisfying for both him and his wife. The client has learned how to "hear" and "react" to his wife's words, because he had not had such experience so far and has not been able to understand such a behavior of his wife. The husband has learned to initiate and maintain a dialogue, whereas earlier he had ignored "some wrong" aspects, by focusing only on the positive life moments, trying to "improve" any "difficult situation" with the wife (when she used to be sad, feeling "not good or feminine enough", or suffering due to exaggerated interference of his mother into their life, etc.). Woman's following (significant to development of synchronization): it has been analyzed whether the woman follows the man's preparation to guide, whether she leans and allows the man feeling trusted, is able to cooperate and wait for the moment of guidance, or she interferes with him and takes the managing initiative. The man's active partnerlike guidance (significant to development of synchronization) is similar to the act of active body language - preparation for guiding and active reaction to the partner, as well as her reaction to the partner's preparation for guiding and the guiding itself these are like the two sides of a coin, which actually constitute the entirety of the couple / family.

The metaphor of the "couple / family life dance" in the research has allowed for methodological orientation of the couple, so that they could focus not only on how they dance, but also to their relationship as a couple, to empathy, to the physical and emotional interpersonal contact of both partners. The common movement in dance and music has enabled not only change in the physical and emotional contact of the couple, but also allowed for creation of new quality of the relationship. The "old" existence in couple has reflected their socially well-established presence in life and their inter-personal life relation, whereas the "new", recently learned existence in couple has presupposed their possible further changes in the social family level.

By applying the essential Gestalt principles (awareness; "here and now"; experience; development) in line with dance and movement therapeutic experiments, the positive result of family counselling has been achieved (in the intra-personal and inter-personal levels): the physical and emotional functioning of both partners has been improved; whereas in the social level husband and wife have proceeded from shaping of diverse figures and discussions to finding the common grounds and dialogue, as well as actions.

\section{Discussion}

All couples and families have it difficult to survive the presence, the daily routine, to solve conflicts and experience, metaphorically speaking, the "life dance in the field of silent aggression or open fire", when there are a lot of inter-personal problems and unexpressed emotions that overwhelm the life of couple and family as a system. Based on the theoretical material and the case study provided herein, 
the article claims that it is important, according to S. Robinson (2010), to help the families of soldiers and sailors not only to understand what they can expect, when their partners come back home from training, missions, battlefields or the sea... It is vital to learn how to understand another member of the couple / family, having the experience of the statutory relations or battlefield aside from the peaceful routine.

The family of the statutory officials must learn to accept the challenges and develop new skills, when the daily life of the couple or family is divided into separate fragments incorporating very different emotional or social experiences: being together and being separated. Psychological, emotional, social wellbeing of the couple and family depends on how effectively they manage to combine these different fragments of the couple and family into a single, continuous whole, replacing the character of the contact with another person, becoming more aware of oneself and the other, as different people with their own special, dissimilar experiences. This will allow the couple or family overcoming the emotional cycles safely, by creating new reliable common experience.

The research done by Sayers (2011) has shown that there exists a negative relation between military service and relationship of the spouses and family, which can be improved by applying long-term integration programs. Similarly, the authors of this article, upon having analyzed the theoretical and practical particularities of Gestalt therapy through the case study, have shown that it is possible to change the relationship and interactions of a couple and family effectively, by applying dance and movement therapeutic experiments. According to Robinson (2010), it is important to disperse the information on the availability of the educational, psychological and psychotherapeutic assistance for couples and families. "The tango brings out the true essence of the individuals, it removes every mask and stops the lies you tell yourself, forcing the contact with yourself even in front of the others. This is the essence on which we relied to propose a course of psychotherapy with basic elements of AT, as a peculiar mode of experiencing oneself" (D'Erricol et al., 2014). The intensity with which tango is practiced seems to depend to some degree on individual lifestyles (Kreutz, 2008). Taken together, the results suggest a high degree of personal involvement in tango dance as a primary leisure activity. This has also been proven by the qualitative research of the couple conducted by the authors of this article.

\section{Conclusions}

1. The essential principles of Gestalt therapy in applying dance and movement therapeutic experiments for couples and families, who start creating their couple life or are willing to change, improve their current presence in the couple or in the family, are as follows: 1) adults are subject to change according to the theory of neuroplasticity (Fishbane, 2013) and actually perceived verbal and non-verbal dialogue of the couple; 2) a couple and family possess the potential to engage in development of the perceived dialogue not only through the Gestalt 
therapy experiments, but also individually, in their own lives; 3) the Gestalt therapy sessions reveal the importance of perception of the interactions between both partners and their co-existence, since it is the dance of their mutual life, during which a perceived experience is gained from the other partner's perspective, which will lead to the dance "without treading on the partner's toes".

2. The qualitative results of the research, upon application of the metaphor of the "couple and family life dance" have been identified in the following categories: 1) dual reversibility: exchange of the same behavior; 2) interaction synchronization; 3 ) other possible models of the couple and family life dance. The model of "suffering and competitive life dance" is stopped by Gestalt therapy; the partners are encouraged through therapeutic, interactive experiments to build more cooperative models based on empathic relationships of "I and You", supporting the development of "self" in a different way.

\section{Literature}

1. Bourdieu, P. 2005. The Rules of Art. 2nd ed. Cambridge: Polity Press.

2. Brownell, Ph., Meara, A. \&. Polák, A. (2008). Ground by Which to Think about Research in Gestalt Therapy. In Brownell, Ph. (ed.). Handbook for Theory, Research, and Practice in Gestalt Therapy. Cambridge Scholars Publishing, (pp. 2-26).

3. Brown, S., Martinez, M., and Parsons, L. (2006). The Neural Basis of Human Dance. Cereb. Cortex 16, 1157-1167.

4. Cikalova, O., Danguole Drungiliene, D., Mockiene, V. (2013). Privalomosios pradinès ir profesionalios karo tarnybų karių patiriamo streso analizè. / Analysis of Stress Experienced by Soldiers of Compulsory Conscription and Professional Military Services. Sveikatos mokslai, 23(1):83-90.

5. Clarkson, P. (2014). Gestalt Counseling in Action. London: Sage Publication Company. http://uk.sagepub.com/sites/default/files/upm-binaries/57778_Clarkson_ with_Cavicchia.pdf

6. Chaiklin, S. and Schmais, D. (1986). The Chace Approach to Dance Therapy, in P Lewis (ed) Theoretical Approaches to Dance/Movement Therapy, 1. Iowa: Kendall/Hunt, (pp. 17-36).

7. D'Errico1, Immacolata, Domenico Mastrofilippo1, Nicoletta De Marzo3 \& Marcello Nardini. (2014). Gotan Project: Tango, a Dance to Experience Oneself. Psychiatria Danubina, 26, Suppl. 1:71-74.

8. Fishbane, M.D. (2013). Loving with the Brain in Mind: Neurobiology and Couple Therapy (Norton Series on Interpersonal Neurobiology. W.W. Norton \& Company Inc. http://books.wwnorton.com/books/Loving-with-the-Brain-in-Mind/

9. Fishbane, M.D. (2001). Relational-Narratives-of-the-Self. Family Processes, 40(3):19. http://www.scribd.com/doc/104498985/Relational-Narrativesof-the-Self-by-Mona-DeKoven-Fishbane\#scribd 
10. Fishbane, M.D. (1998). I, Thou, and We: A Dialogical Approach to Couples Therapy. Journal of Marital and Family Therapy, 24(1):41-58.

11. Francesetti, G. et al., (2013). Gestalt Therapy Approach to Psychopathology. In Francesetti, G., Gecele, M., Roubal, J. (ed.). Gestalt Therapy in Clinic Practice. From Psychopathology to the Aesthetics of Contact. Gestalt Therapy Book Series. FrancoAngeli, Milano, (pp. 59-60).

12. Gallese, V., Eagle, M.E., \& Migone, P. (2007). Intentional Attunement: Mirror Neurons and the Neural Underpinnings of Interpersonal Relations. Journal of the American Psychoanalytic Association, 55:131-176.

13. Globalizacijos iššūkiai ugdymo procesui: visuomenè ir kariuomenè. / Challenges of Globalization in Educational Process: the Society and the Army. Mokslo studija. (2013). Atsakingoji redaktore / Chief Editor doc. dr. Audrone Petrauskaitè. Vilnius: Generolo Jono Žemaičio Lietuvos karo akademija

14. Grakauskaitė-Karkockienė D. (2011). Komunikacinė šeimos teorija (V. Satir šeimos rekonstrukcijos metodas). / Family Communication Theory (V. Satir's family reconstruction method). In Šeimos psichologija. Vilnius: Lietuvos edukologijos universiteto leidykla, (pp.121-122).

15. Habib, M. (2005). Tango and Mirror Neurons: a Neurological Theory for an Universal Artistic Genre. http://www.resodys.org/IMG/pdf/neuronas_ espejoMdPlatared.pdf

16. Hackney, M., \& Earhart, G. (2010). Social Partnered Dance for People with Serious and Persistent Mental Illness: a Pilot Study. J. Nerv. Ment. Dis. 198:76-78.

17. Hatch, S.L., Harvey, S.B., Dandeker, C., Burdett, H., Greenberg, N., Fear, N.T., et al. (2013). Life in and after the Armed Forces: Social Networks and Mental Health in the UK Military. Sociology of Health \& Illness, 35(7):1045-1064.

18. Hagendoorn, I. (2005). Dance Perception and the Brain. In Grove, R., Stevens, C. and McKechnie, S. eds. Thinking in Four Dimensions. Melbourne: Melbourne University Publishing. (pp.137 - 148).

19. Hangendoorn, I. (2011). Dance, Choreography and the Brain. In Melcher, D. and Bacci F. (eds). Art and the Senses. Oxford: Oxford University Press, (pp. $499-514)$.

20. Iversen, A., van Staden, L., Hughes, J., Browne, T., Hull, L., Hall, J., et al. (2009). The Prevalence of Common Mental Disorders and PTSD in the UK Military: Using Data from a Clinical Interview-based Study. BMC Psychiatry, 9-68.

21. Iversen, A.C., van Staden, L., Hughes, J.H., Browne, T., Greenberg, N., Hotopf, M., et al. (2010). Help-seeking and Receipt of Treatment among UK Service Personnel. The British Journal of Psychiatry, 197:149 - 155.

22. Johansson, A. (2009). Narratives about Gestalt-therapeutic Couple Therapy: What Makes a Couple Come to Couple Therapy and What Helps in Couple Therapy? Master of Science Gestalt Psychotherapy. Dissertation in sociology.

23. Jonkus, D. (2009). Patirtis ir refleksija: fenomenologines filosofijos akiračiai / Experience and Reflection: Phenomenological Philosophy Horizons. Kau- 
nas: Vytauto Didžiojo universiteto leidykla.

24. Karkou, V. (2009). Forming Therapeutic Relationships in Dance Movement Psychotherapy: The Role of Mirroring. Interdisciplinary Panel 2: Kinesthetic Experience and Embodied Practices.

25. Karkou, V.\& Sanderson, P. (2006). Arts Therapies: A Research: BasedMap of the Field. Edinburgh: Elsevier.

26. Kattenstroth J-C, Kalisch T, Holt S, Tegenthoff, M and Dinse, H.R. (2013). Six Months of Dance Intervention Enhances Postural, Sensorimotor, and Cognitive Performance in Elderly without Affecting Cardio-respiratory Functions. Front. Aging Neurosci. 5:5.

27. Kepner J. (1987). Body Process: a Gestalt Approach to Working with the Body in Psychotherapy. New York: Gardner.

28. Kim, J. \& Daniels, V. (2008). Experimental Freedom. Chapter 3. In P. Brownell (ed.) Handbook for Theory, Research and Practice in Gestalt Therapy. UK: Cambridge Scholars Publishing, (pp. 198- 228).

29. Kreutz, G. (2008). Does Partnered Dance Promote Health? The Case of Tango Argentino. J. R. Soc. Promot. Health 128:79-84.

30. Lahood, G.A. (2013). Therapeutic Democracy: the Roots and Potential Fruits of a Gestalt-assisted Collaborative Inquiry. Gestalt Review, 17(2):119-148.

31. Lee, R. (2007). The Secret Language of Intimacy: Releasing the Hidden Power in Couple Relationships. Mahwah, NJ: Analytic Press.

32. Levite, Z. \& Cohen, O. (2012a). The Tango of Loving Hate: Couple Dynamics in High-conflict Divorce Clinical Social Work Journal, 40(1):46.

33. Clinical Social Work Journal, 40(1):46

34. Levite, Z. \& Cohen, O. (2012b). High-conflict Divorced Couples: Combining Systemic and Psychodynamic Perspectives. Journal of Family Therapy, 34(4):387-402.

35. Loeschen, S. (1998). Systematic Training in the Skills of Virginia Satir. Pacific Grove, CA: Brooks/Cole.

36. Maslauskaite, A. (2005). Šeima ir šeimos politika: patirtis ir neokonservatyvios politikos gaires / Family and Family Policy: Experience and NeoConservative Policy Guidelines. Vilnius: STI.

37. Mearleau-Ponty, M. (2002). The Phenomenology of Perception. London: Routledge and Keegan.

38. Mebius, J. (2009). Narratives about Gestalt-therapeutic Couple Therapy: What Makes a Couple Come to Couple Therapy and What Helps in Couple Therapy? Dissertation Master of Science Gestalt Psychotherapy. Superviser Johansson, A. Gestalt Akademin Skandinavien / University of Derby.

39. Meekums. B. (2005). Dance Movement Therapy. A Creative Psychotherapeutic Approach. London: SAGE Publications.

40. Meekums B, Karkou V, Nelson EA. (2015). Dance Movement Therapy for Depression. Cochrane Database of Systematic Reviews, 2. http://onlinelibrary. 
wiley.com/enhanced/doi/10.1002/14651858.CD009895.pub2

41. Miller, M. V. (1995). Intimate Terrorism: the Deterioration of Erotic Life. New York: W. W. Norton \& Company.

42. Miller, M. V. (1994). Introduction to Gestalt Therapy. In F. S. Perls, R. F. Hefferline, \& P. Goodman (Eds.), Gestalt therapy: Excitement and Growth in the Human Personality. New York: Gestalt Journal Press.

43. Moller, A.R. (ed). (2006). Reprogramming the Brain. Progress in Brain Research, 157:1-379.

44. Nevis, E. C. (1987). Organizational Consulting: a Gestalt Approach. Cleveland: Gestalt Institute of Cleveland Press

45. Oliver, S. (2009). Community-based Creative Dance for Adolescents and Their Feelings of Social Wellbeing. A thesis submitted in partial fulfilment of the requirements of the degree of Doctor of Philosophy. Queen Margaret University.

46. Olivieri, M., Fiebert, M.S. (2013). Integrating Couple Polarities through Gestalt Counseling. International Review of Social Sciences and Humanities, 5(1): 164-174.

47. Perls, F., Hefferline, R. F., \& Goodman, P. (1951). Gestalt Therapy: Excitement and Growth in the Human Personality. New York: Gestalt Journal Press.

48. Proske, U. \& Gandevia, S.C. (2012). The Proprioceptive Senses: their Roles in Signaling Body Shape, Body Position and Movement, and Muscle Force. Physiological Reviews, 92(4): 1651-1697.

49. Puzinavicius B. (2001). Bendrosios ir karo psichologijos pagrindai/ Basics of General and War Psychology. Generolo J. Žemaičio Lietuvos karo akademija, Vilnius, 2:5.

50. Polo, G. (2010). The Space between Us: the Experience of Relationship in the Argentine Tango. Dance/Movement Therapy \& Counseling Theses. Paper 14.

51. Puzinavicius B. (2007). Karių tarpasmeninių santykių ypatybès ir problemos. Karinis rengimas ir ugdymas Lietuvoje / Characteristics and Problems of Soldiers' Interpersonal Relationship. Military Training and Education in Lithuania. Generolo Jono Žemaičio Lietuvos karo akademija, Vilnius, 222.

52. Resnick, S. (2004). Somatic-Experiential Sex Therapy: A Body-Centered Gestalt Approach. Gestalt Review, 8 (1): 40-64.

53. Riemann, G. \& Schütze, F. (1991). "Trajectory" as a Basic Theoretical Concept for Analyzing Suffering and Disorderly Social Processes. In: Maines, DR. (Ed.): Social Organization and Social Process: Essays in Honor of Anselm Strauss. New York: de Gruyter, (pp. 333-357).

54. Rizzolatti, G et al (1996) Premotor Cortex and the Recognition of Motor Actions, Cognitive Brain Research, 3: 131-141.

55. Robinson,, S. (2010). On The Military Family. http://www.pbs.org/ thisemotionallife/blogs/war-military-family.

56. Roubal, J. (2009). Experiment: a Creative Phenomenon of the Field, Gestalt Review, 13(3):263-276. 
57. Roubal, J. (2007). Depression - a Gestalt Theoretical Perspective. British Gestalt Journal, 16 (1):35-43.

58. Roubal, J. (2004) Gestalt Approach in the Therapy of Depression. Konfrontace, 15 (1):31-36.

59. Salmons, C.A. (2014). Dance for your Life! TangoFlow!® Technique and Implications in the Treatment of Trauma. A mixed-methods empirical study based upon independent investigation. Submitted in partial fulfillment of the requirements for the degree of Master of Social Work. Catherine A. Salmons Smith College School for Social Work. Northampton, Massachusetts 01063.

60. Samaritter, R. (2009): The Use of Metaphors in Dance Movement Therapy, Body, Movement and Dance in Psychotherapy: An International Journal for Theory, Research and Practice, 4:1, 33-43.

61. Sartori, R. \& Steidl, P. (2003). Tango: šokio erotinio prado galia / Tango: Power of Erotic Origin of Dance. Vilnius; Tyto alba.

62. Satir, V. (1983). Conjoint Family Therapy (3rd ed.). Palo Alto, CA: Science and Behavior Books.

63. Satir, V. (1988). The New Peoplemaking. Palo Alto, CA: Science and Behavior Books.

64. Satir, V., \& Baldwin, M. (1983). Satir Step by Step: a Guide to Creating Change in Families. Palo Alto, CA: Science and Behavior Books.

65. Satir, V., Banmen, J., Gerberm J. \& Gomori, M. (1991). The Satir Model: Family Therapy and Beyond. Palo Alto, CA: Science \& behavior Books, Inc.

66. Scheinkman, M., Fishbane, D.M. (2004). The Vulnerability Cycle: Working With Impasses in Couple Therapy. Fam Proc, 43:279-299.

67. Sevdalis, V. \& Keller, P.E. (2011). Captured by Motion: Dance, Action Understanding and Social Cognition. Brain and Cognition, 77:231-236.

68. Spagnuolo Lobb, M. (2003). Therapeutic Meeting as Improvisational Co-creation. In M. Spagnuolo Lobb \& N. Amendt-Lyon (Eds.), Creative license: The Art of Gestalt Therapy. New York: Springer, (pp. 37-49).

69. Spagnuolo Lobb, M. (2009). Is Oedipus still Necessary in the Therapeutic Room? Sexuality and Love as Emerging at the Contact-Boundary in a Situational Field. Gestalt Review, 13(1):47-61.

70. Stankuniene V., Jasilioniene A., Mikulioniene S., Mitrikas A., Maslauskaite A. (2003). Šeimos revoliucija? Iššūkiai šeimos politikai / Family Revolution? Challenges for Family Policy. Vilnius: STI.

71. Stankunienė V., Jonkaryte A., Mitrikas A. (2003a) Šeimos transformacija Lietuvoje: požymiai ir veiksniai / Family Transformation in Lithuania: Features and Factors. Filosofija. Sociologija, 2:51-58.

72. Stevenson, H. (2015). Gestalt Principles. http://www. clevelandconsultinggroup.com/articles/gestalt-principals.php

73. Štrimas, G. (2007). Ne visi kariauja vienodai / Not All Fighting the Same. Kardas, 2(425). 
74. Thompson, A. \& Harper, D. (Eds.) (2012). Qualitative Research Methods in Mental Health \& Psychotherapy: an Introduction for Students \& Practitioners. Chichester, UK: Wiley-Blackwells, (pp. 69-81).

75. Yontef, G.M., \& Simkin, J.S. (1989). Gestalt Therapy. In R. J. Corsini \& D. Wedding (Eds.), Current Psychotherapies New York: Peacock, (pp. 323-361).

76. Yontef, G. \& Bar Yoseph, T. (2008) Dialogic Relationship. Chapter 9. In P. Brownell (ed.) Handbook for Theory, Research, and Practice in Gestalt Therapy UK: Cambridge Scholars Publishing, (pp. 184-197).

77. Zinker, J.C. (1977). Creative Process in Gestalt Therapy. New York: Vintage Books.

78. Zinker, J.C. (1983). Complementary and the Middle Ground in Couples, Gestalt Journal, 6(2):13-27.

79. Zinker, JC. (1994). In Search of Good Form: Gestalt Therapy with Couples and Families. Massachusetts: GIC Press. Second Printing.

80. Zukauskienè, L., Virsilas, V. (2005). Lietuvos jūrininkų saviugdos poreikiai XXI a. pradžioje: vertybinis aspektas / The Seamen's Needs of the Selfeducation at the Beginning of XXI Century: the Valuable Aspect. Pedagogika, 57-62.

81. Wagner-Moore, L. (2004). Gestalt Therapy: Past, Present, Theory, and Research. Psychotherapy: Theory, Research, Practice, Training, 41(2): 180-189.

82. Warwar, S., Hollis-Walker, L., Monette, G., Angus, L. E., \& Boritz, T. Z. (2011). Narrative and Emotion Integration in Psychotherapy: Investigating the Relationship between Autobiographical Memory Specificity and Expressed Emotional Arousal in Brief Emotion-focused and Client-centered Treatments of Depression. Psychotherapy Research, 21(1): 16-26.

83. Wheeler, G. (1991). Gestalt Reconsidered: a New Approach to Contact and Resistance. New York: Gestalt Institute of Cleveland Press.

84. Wheeler, G. (2003) Contact and Creativity: The Gestalt Cycle in Context. In M. Spagnuolo Lobb \& N. Amendt-Lyon (Eds.), Creative license: The Art of Gestalt Therapy. New York: Springer, (pp. 162-170).

85. Wheeler, G. \& Beckman, S. (red) (1994) On Intimate Ground: a Gestalt Approach to Working with Couples. San Francisco, California: A Gestalt Institute of Cleveland Publication.

86. Winters, A.F. (2008) Emotion, Embodiment and Mirror-Neurons in Dance/Movement Therapy: A Connection Across Disciplines. American Journal of Dance Therapy, 30(2):84-105.

87. Woodley, K., Sotelano, M. (2010). Tango Therapy 2, Research and Practice. London: Tango Creations Publishers.

88. Vukadinović, M. \& Marković, S. (2011). Aesthetic Experience of Dance Performances. Psichologija, 45(1):23-41. 


\title{
GEŠTALTO PSICHOTERAPIJA KARIŲ IR JŪREIVIŲ POROMS BEI ŠEIMOMS, TAIKANT ŠOKIO IR JUDESIO TERAPINIUS EKSPERIMENTUS
}

\author{
Dr. Laima Sapežinskienè \\ Lietuvos sveikatos mokslu universiteto Elgesio medicinos institutas
}

\author{
Alvydas Soraka \\ Klaipédos universiteto Menu akademijos Šokio katedra
}

Daina Milikauskienè

Lietuvos sveikatos mokslu universiteto Elgesio medicinos institutas

\section{Santrauka}

Geštalto psichoterapijos atstovė Virginija Satir, kurią galima pavadinti Amerikos šeimos terapijos motina, tvirtino, kad santuokos terapijos tikslas yra „ne išlaikyti santykius ar išskirti porą, bet padèti partneriams pasirūpinti savimi“. Būtent efektyvios poros terapijos centre yra partnerių diferenciacija, o ne siekimas juos suvienodinti ir priderinti viens prie kito. Mokslinio tyrimo klausimas: kaip padèti karių ir jūreivių poroms bei šeimoms pereiti iš kentejimo trajektorijos ị kūrybinę savo gyvenimo kūrimo (sąmoningumo) trajektoriją, kaip, siekiant sumažinti psichosocialines problemas bei konfliktus vidiniame asmeniniame ir tarpasmeniniame santykių lygmenyje, kariams ir jūreiviams kūrybiškai saugiai pereiti iš statutinio ị civilinị gyvenimą? Tikslas: atskleisti, kaip galima konsultuojant karių ir jūreivių poras bei šeimas geštalto psichoterapijoje, taikyti šokio ir judesio terapinius eksperimentus. Tyrimo metodologija apima geštalto psichoterapijoje naudojamą teorinị paaiškinimą, vadinamą socialinio kontakto patyrimo (eksperimento) ciklu. Geštalto psichoterapijoje tiriama, kiek pora ar šeima kontaktuoja, turi santykių ir sąveikauja tarpusavyje (Zinker 1994; Wheeler ir Beckman 1994), kaip ji iš kūrybinès tuštumos trajektorijos gali pereiti ị save patenkinantị ar nepatenkinantị aktyvumą. Taikyti fenomenologiniai kokybiniai tyrimo metodai. Duomenys buvo analizuoti ir tvarkyti turinio analizès (angl. content analyze) būdu. Tyrime dalyvavo šeima, kuri lankė geštalto psichoterapijos konsultacijas (viso 10 sesijų). Kiekviena sesija truko 1,5 val. 5 sesijos buvo skirtos verbalinei psichoterapijai, o kitų 5 sesijų metu buvo taikomi šokio judesio terapiniai eksperimentai (argentinietiškas tango). Pateikti teorinio-praktinio porų, šeimų pokyčių tyrimo rezultatai, apibrèžti keliomis kategorijomis: 1) dualiniu grịžtamumu, t. y. pasikeitimu tokiu pačiu elgesiu; 2) sąveikos sinchronizacija ir 3) poros ar šeimos „gyvenimo šokio“ kitais kūrybiniais modeliais (trajektorijomis). Esminè išvada yra ta, kad, konsultuojant karių ir jūreivių poras bei šeimas geštalto psichoterapijoje, taikant šokio ir judesio terapinius eksperimentus, galima padèti kariams ir jūreiviams bei jų sutuoktiniams pereiti iš kentėjimo trajektorijos į kūrybinę savo gyvenimo kūrimo (sąmoningumo) trajektoriją, mažinant nutolimą ir susigrąžinant tarpusavio santykių gyvybingumą, ir igyti patirties, suvokti gyvenimą iš kito partnerio perspektyvos.

Pagrindiniai žodžiai: geštalto psichoterapija, kontakto ciklo patyrimas; šokio ir judesio eksperimentai, poros / šeimos gyvenimo šokis, argentinietiškas tango. 


\section{AUTORIŲ LYDRAŠTIS}

Autoriaus vardas, pavardè: Laima Sapežinskienè

Mokslo laipsnis ir vardas: socialinių mokslų (sociologija) daktaro laipsnis

Darbo vieta ir pareigos: Lietuvos sveikatos mokslų universiteto Medicinos akademijos Elgesio medicinos instituto mokslo darbuotoja

Autoriaus mokslinių interesų sritys: visuomenès požiūris ị negalią ir neiggaliuosius, neigaliụjų ir neturinčių negalios ugdymas šokiu; šokio / judesio terapija kaip konkrečios jų psichoemocinès ir socialinès būsenos išraiška

Telefonas ir el. pašto adresas: 861414 543; marija1000@gmail.com

Autoriaus vardas, pavardè: Alvydas Soraka

Mokslo laipsnis ir vardas: sporto magistro laipsnis

Darbo vieta ir pareigos: Klaipėdos universiteto Menų akademijos Šokio katedros docentas

Autoriaus mokslinių interesų sritys: vaikų ugdymas; ugdymas šokio menu; ugdymas poriniais sportiniais šokiais; neigaliųų ugdymas šokiu; šokio ir judesio terapija

Telefonas ir el.pašto adresas: 869815 711; alvydas.soraka@gmail.com

Autoriaus vardas, pavardè: Daina Milikauskienè

Mokslo laipsnis ir vardas:-

Darbo vieta ir pareigos: Lietuvos sveikatos mokslų universiteto Medicinos akademijos Elgesio medicinos instituto savanorè- tyreja

Autoriaus mokslinių interesų sritys: psichoterapijos; šokio ir judesio psichoterapijos tyrimai; vaikų ugdymas; ugdymas šokio menu; porinių sportinių šokių ugdymas; neigaliųų ugdymas šokiu; šokio ir judesio terapija

Telefonas ir el. pašto adresas: 8 699-86069; dainele@gmail.com 


\section{AUTHORS' COVER LETTERS}

Author's name and surname: Laima Sapežinskienė

Academic degree and name: Doctor of Social Sciences (Sociology)

Workplace and position: Lithuanian University of Health Sciences, Medical Academy, Institute of Behavioural Medicine, Laboratory of Psychosomatic Research, Researcher

Author's research interests: society attitudes towards disabilities and the disabled, education of the disabled and non-disabled; dance and movement therapy as the manifestation of their specific psycho-emotional and social status

Telephone and e-mail address: +370 61414 543; marija1000@gmail.com

Author's name and surname: Alvydas Soraka

Academic degree and name: Master of Sports

Workplace and position: Klaipėda University, Academy of Arts, Dance Department, Associate Professor

Author's research interests: children's education, dance arts education; couple sport dance education, dance education of persons with disabilities, dance and movement therapy

Telephone and e-mail address: +370 69815 711; alvydas.soraka@gmail.com

Author's name and surname: Daina Milikauskienè

Academic degree and name:

Workplace and position: Lithuanian University of Health Sciences, Medical Academy, Institute of Behaviour Medicine, Laboratory of Psychosomatic Research, Volunteer-Researcher

Author's research interests: research of psychotherapy and dance/movement psychotherapy; children's education, dance arts education; couple sport dance education, dance education of persons with disabilities, dance and movement therapy

Telephone and e-mail address: +370 69986 069; dainele@gmail.com 